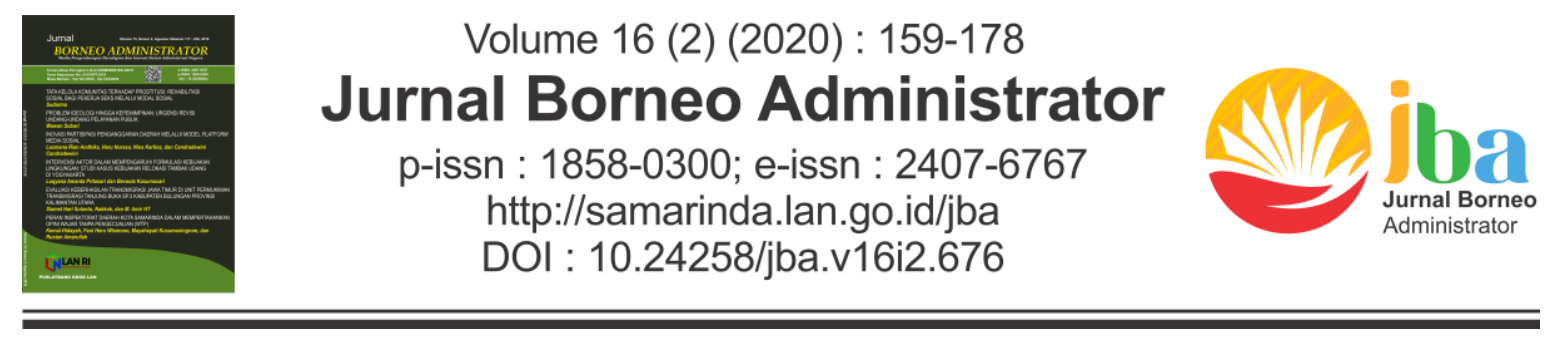

\title{
IMPLEMENTASI KEBIJAKAN PENGEMBANGAN KAWASAN EKONOMI KHUSUS TANJUNG KELAYANG
}

\section{POLICY IMPLEMENTATION OF TANJUNG KELAYANG SPECIAL ECONOMIC ZONE}

\author{
Alvin Rizalsan dan Vishnu Juwono \\ Fakultas Ilmu Administrasi, Universitas Indonesia, \\ Jl. Prof. Dr. Selo Soemardjan, Depok \\ E-Mail: alvinrizalsan@gmail.com; vjuwono@ui.ac.id
}

Naskah diterima: 11 April 2020; revisi terakhir: 13 Juli 2020; disetujui 30 Juli 2020

How to Cite: Rizalsan, Alvin., dan Juwono, Vishnu. (2020). Implementasi Kebijakan Pengembangan Kawasan Ekonomi Khusus Tanjung Kelayang. Jurnal Borneo Administrator, 16 (2), 159-178. https://doi.org/10.24258/jba.v16i2.676

\begin{abstract}
Tanjung Kelayang, as a tourism SEZ (Special Economic Zone), has some difficulties with land disputes and unfulfilled investment targets. This paper attempts to study the implementation with streams/critical juncture approach and rational implementation model. This study was conducted with a postpositivist approach and data collection by conducting in-depth interviews and literature studies as secondary data. The study showed that the SEZ was BUPP innovation to develop bussiness with incentives from the government. The government sees this as an opportunity to increase community development. The implementation of the policy was carried out with lots of actors from the government and BUPP. The problem with investment in SEZ is that the investors choose to wait and see. In terms of the important factor that influenced the implementation are unclear vision and mission, unfulfilled investment target, and monitoring without the ability to intervene..
\end{abstract}

Keywords: Special Economic Zone; Tourism; Implementation; Policy

\begin{abstract}
Abstrak
KEK Tanjung Kelayang yang merupakan KEK pariwisata memiliki beberapa kendala, seperti konflik sengketa tanah dan tidak tercapainya target investasi. Tulisan ini mencoba menganalisis implementasi dari Kebijkan KEK Tanjung Kelayang tersebut dengan menggunakan multiple streams/critical juncture approach dan model implementasi rasional. Penelitian menggunakan pendekatan post-positivist dan dilakukan pengumpulan data dengan melakukan wawancara mendalam serta data sekunder dari literatur. Hasil penelitian ini
\end{abstract}


menunjukan bahwa KEK merupakan inisiatif BUPP untuk mengembangkan kawasan dengan insentif dari pemerintah. Pemerintah ikut serta melihat potensi dari pengembangan kawasannya dapat meningkatkan perekonomian masyarakat. Dalam implementasi kebijakan dilakukan oleh banyak aktor-aktor yang terdiri dari pemerintah dan BUPP. Masalah yang menjadi hambatan KEK adalah lambatnya realisasi investasi karena banyak investor yang wait and see. Karena faktor-faktor penting implementasi yang menghambat ada pada indikator visi, misi yang kurang jelas, perencanaan target investasi yang kurang dan pengawasan tanpa kemampuan intervensi.

Kata Kunci: Kawasan Ekonomi Khusus; Pariwisata; Implementasi; Kebijakan

\section{A. PENDAHULUAN}

Indonesia merupakan negara kepulauan yang luas dan kaya akan sumber daya alam yang melimpah. Pancasila yang merupakan dasar Negara Kesatuan Republik Indonesia pada sila kelima menyatakan "Keadilan Sosial bagi Seluruh Rakyat Indonesia". Sila tersebut dapat dimaknai sebagai tujuan atau cita-cita Indonesia untuk memberikan keadilan sosial bagi seluruh rakyat Indonesia. Sila ini dapat diartikan juga sebagai cita-cita bangsa untuk menjadikan masyarakat Indonesia sejahtera, adil, dan makmur. Perwujudan cita-cita tersebut membutuhkan pemerintahan yang berjalan berlandaskan atas azas-azas pemerintahan yang baik. Administrator negara dituntut untuk mampu mementingkan kepentingan masyarakat luas dalam kebijakan yang diambil.

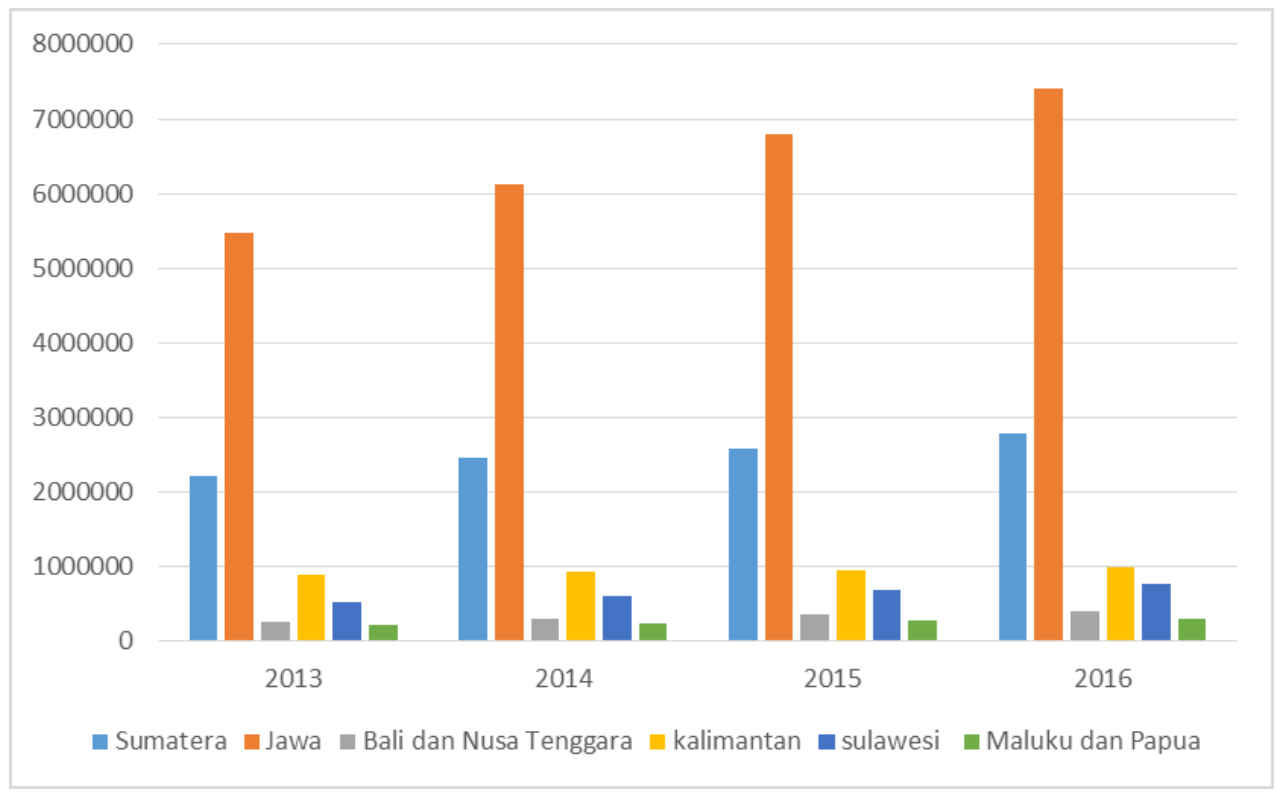

Gambar 1.

PDRB di Indonesia (dalam miliar rupiah) (Sumber: BPS, 2018:17)

Hasil dari kebijakan-kebijakan yang diambil oleh Pemerintah hingga saat ini belum berhasil meratakan kemakmuran, keadilan, dan kesejahteraan masyarakat Indonesia. Hal tersebut tercermin pada perekonomian masing-masing daerah yang masih timpang satu sama lain. Dapat dilihat pada grafik 1, perekonomian masih berpusat di Pulau Jawa dan hanya sebagian kecil perekonomian yang ada di daerah lainnya dilihat dari PDRB daerahnya. 
Ketimpangan ekonomi seperti ini merupakan hal yang biasa terjadi akibat dari perbedaan kondisi daerah tiap-tiap wilayah. Perbedaan ini meliputi kondisi demografi dan keberadaan sumber daya alam yang mengakibatkan perbedaan kemampuan tiap daerah dalam mendorong proses perekonomiannya. Hal tersebut mengakibatkan terbentuknya daerah yang sudah berkembang dan daerah yang belum berkembang (Sjafrizal, 2012:27-38). Perbedaan tersebut juga mengakibatkan perbedaan dalam tingkat pembangunan daerah sehingga menghasilkan gap kesejahteraan di berbagai daerah (Sadono, 2010:34).

Untuk mengatasi permasalahan tersebut, Pemerintah dalam hal ini telah memasukan visi tersebut ke dalam Masterplan Percepatan dan Perluasan Pembangunan Ekonomi Indonesia (MP3EI) 2011-2025 yang bertujuan mewujudkan visi Indonesia 2025, yaitu Indonesia yang mandiri, maju, adil, dan makmur. Adapun MP3EI dalam mewujudkan visi 2025 difokuskan ke dalam tiga misi utama, yakni peningkatan nilai tambah dan perluasan rantai nilai proses produksi serta distribusi dari pengelolaan aset dan akses (potensi) SDA, geografis wilayah, dan SDM, melalui penciptaan kegiatan ekonomi yang terintegrasi dan sinergis di dalam maupun antar-kawasan pusat-pusat pertumbuhan ekonomi, mendorong terwujudnya peningkatan efisiensi produksi dan pemasaran serta integrasi pasar domestik dalam rangka penguatan daya saing dan daya tahan perekonomian nasional dan mendorong penguatan sistem inovasi nasional di sisi produksi, proses, maupun pemasaran untuk penguatan daya saing global yang berkelanjutan, menuju innovation-driven economy (Kementerian Koordinator Bidang Perekonomian, 2011:15).

Berdasarkan misi tersebut, maka salah satu strategi yang dilakukan dalam MP3EI adalah mengembangkan potensi koridor-koridor ekonomi yang tersebar di seluruh wilayah Indonesia. Pemerintah dalam hal ini mendorong pengembangan bagi koridor ekonomi baru ataupun yang sudah ada dengan memanfaatkan potensi keunggulan tiap-tiap wilayah di Indonesia. Indonesia saat ini mempunyai enam koridor ekonomi, yaitu: Koridor Sumatera, Koridor Jawa, Koridor Kalimantan, Koridor Sulawesi, Koridor Bali-Nusa Tenggara dan Koridor Papua-Kepulauan Maluku. Dalam pengembangan Koridor Ekonomi dilakukan melalui pengembangan Kluster Industri dan Kawasan Ekonomi Khusus (Kementerian Koordinator Bidang Perekonomian, 2011:46).

Aturan awal yang menyingung mengenai Kawasan Ekonomi Khusus terdapat dalam BAB XIV Pasal 31 Undang-Undang Nomor 25 Tahun 2007 tentang Penanaman Modal (Undang-Undang Nomor 25 Tahun 2007 Tentang Penanaman Modal, 2007). Pasal tersebut mengatur mengenai tujuan strategis dari Kawasan Ekonomi Khusus yang digunakan untuk pengembangan ekonomi nasional dan menjaga keseimbangan kemajuan daerah. Aturan lebih lanjut yang mengatur Kawasan Ekonomi Khusus kemudian baru ditetapkan pada tahun 2009 malalui Undang-Undang Nomor 39 Tahun 2009 yang mengatur tentang Kawasan Ekonomi Khusus (Undang-Undang Nomor 39 Tahun 2009 Tentang Kawasaan Ekonomi Khusus, 2009).

Berdasarkan Rancangan Pembangunan Jangka Menengah Nasional (RPJMN) 20152019 Pemerintah sebenarnya telah menargetkan pada tahun 2019 Indonesia memiliki total sebanyak 25 Kawasan Ekonomi Khusus (Dewan Nasional Ekonomi Khusus, 2018:3). Sedangkan hingga saat ini jumlah Kawasan Ekonomi Khusus yang telah ditetapkan baru berjumlah $12 \mathrm{KEK}$, Sehingga sampai saat ini baru terdapat penambahan empat Kawasan Ekonomi Khusus dari semula 8 KEK pada tahun 2014. Kawasan Ekonomi Khusus (KEK) telah berkontribusi dalam mengembangkan perekonomian di berbagai negara, walaupun juga terdapat negara-negara yang belum berhasil dalam mengembangkan KEKnya (Moberg, 2015:167). KEK dari berbagai negara memiliki kesamaan tujuan, yakni meningkatkan investasi, mengurangi batasan operasi, dan memfasilitasi investor (Pakdeenurit et al., 
2014:5). Pemerintah Indonesia menargetkan untuk menambah sebanyak tujuh Kawasan Ekonomi Khusus pariwisata hingga tahun 2019. Hal itu terlihat pada tingginya potensi pariwisata di Indonesia yang ditujukan, baik bagi wisatawan domestik maupun mancanegara. Potensi wisata Indonesia kaya akan sumber daya alam yang beragam, seperti wisata alam, pantai, bahari, kepulauan, air terjun, dan ekowisata lainnya. Selain itu, Indonesia juga kaya akan kebudayaan masyarakatnya yang menarik bagi para wisatawan untuk ditelusuri. Terdapat tiga manfaat ekonomi yang dapat dihasilkan pariwisata bagi negara berkembang, yakni menghasilkan pendapatan, kesempatan kerja, dan devisa negara (Bhuiyan et al., 2013:11).

Pemerintah dalam hal ini telah menetapkan beberapa kawasan ekonomi khusus pariwisata dalam beberapa tahun terakhir. Kawasan ekonomi khusus pariwisata yang baru ditetapkan salah satunya adalah Kawasan Ekonomi Khusus Tanjung Kelayang. Kawasan Ekonomi Khusus Tanjung Kelayang ditetapkan pada tahun 2016 melalui Peraturan Pemerintah Nomor 6 Tahun 2016. Kawasan Ekonomi Khusus Tanjung Kelayang ditetapkan di lahan seluas 324.4 Ha yang berstatus sebagai Hak Guna Bangunan (HGB) yang berada di wilayah Kabupaten Belitung, Provinsi Bangka Belitung. Kawasan Ekonomi Khusus Tanjung Kelayang merupakan salah satu dari empat kawasan ekonomi khusus yang baru dibentuk setelah tahun 2014. Kawasan Ekonomi Khusus Tanjung Kelayang memiliki keunikan dibandingkan dengan kawasan ekonomi khusus lainya yang mana proses penetapan hingga dimulainya pembangunan merupakan yang paling cepat dibandingkan dengan kawasan ekonomi khusus lainnya. Proses pembangunan KEK dimulai pada tanggal 2 September 2016 atau sekitar 6 bulan dari tanggal penetapannya pada 18 Maret 2016. Realisasi tersebut jauh lebih cepat dibandingkan dengan Kawasan Ekonomi Khusus lain yang rata-rata membutuhkan waktu $2-3$ tahun dari penetapan hingga peletakan batu pertama ( $\underline{\mathrm{CNN}}$ Indonesia, 2016).

Kegiatan pengembangan Kawasan Ekonomi Khusus Tanjung Kelayang berfokus pada pembangunan dan pengelolaan kawasan serta pariwisata. Pengembangan Kawasan Ekonomi Khusus Tanjung Kelayang ditargetkan dapat membawa investasi dari pelaku usaha sebesar Rp20 Triliun dan juga pembangunan kawasan sebesar Rp1,5 Triliun (Dewan Nasional Ekonomi Khusus, 2018:30). Dengan investasi tersebut diharapkan pada tahun 2022 pariwisata di Kawasan Ekonomi Khusus Tanjung Kelayang dapat meningkatkan PDRB regional sebesar Rp1,3 Triliun dan menyerap sebanyak 23.645 tenaga kerja. Pemerintah dalam masterplan pembangunan Kawasan Ekonomi Khusus Tanjung Kelayang terdapat 19 investasi pembangunan fasilitas pariwisata yang tersebar di wilayah kawasan itu.

Pengembangan Kawasan Ekonomi Khusus Tanjung Kelayang yang telah dilakukan oleh pemerintah bekerja sama dengan pihak swasta tidak sepenuhnya berjalan tanpa hambatan. Lahan yang menjadi tempat berdirinya Kawasan Ekonomi Khusus Tanjung Kelayang masih menjadi sengketa antara masyarakat setempat dan perusahaan dari Belitung Maritime selaku konsorsium pengelola Kawasan Ekonomi Khusus Tanjung Kelayang. Perusahaan tersebut, antara lain PT Belitung Pantai Intan (PT Belpi), PT Nusa Kukila, dan PT Tanjung Kasuarina yang menyatakan memiliki hak atas tanah tersebut. Untuk menyelesaikan sengketa tanah kemudian pada tanggal 29 Agustus 2017 dibentuk Tim Tri Partit yang merupakan gabungan dari unsur Pemerintah, masyarakat, dan PT Belitung Pantai Intan (PT Belpi) untuk menghimpun fakta-fakta yang ada di lapangan guna menyelesaikan sengketa lahan antara masyarakat dan perusahaan Konsorsium Belitung Maritime (Belitongekspres, 2017).

Masalah lain yang terdapat dalam proses pengembangan Kawasan Ekonomi Khusus Tanjung Kelayang adalah tidak tercapainya target pembangunan investasi Hotel Sheraton. 
Pembangunan ditargetkan selesai dan dapat beroperasi pada agustus 2018 tetapi hingga tahun 2019 pembangunan hotel tersebut masih belum diselesaikan oleh kontraktor (Dewan Nasional Ekonomi Khusus Republik Indonesia, 2017). Mengingat investasi pembangunan tersebut merupakan salah satu dari proyek pembangunan Hotel bintang 5 yang dicanangkan untuk Kawasan Ekonomi Khusus Tanjung Kelayang. Dengan terlambatnya pembangunan Hotel tersebut akan membawa dampak pada kesiapan operasional KEK Tanjung Kelayang yang diharapkan sudah beroperasi pada tahun 2019.

Masalah yang dihadapi oleh Kawasan Ekonomi Khusus Tanjung Kelayang juga menjadi perhatian dari Pusat Penelitian Ekonomi Lembaga Ilmu Pengetahuan Indonesia (LIPI) yang telah melakukan penelitian di Kawasan Ekonomi Khusus Tanjung Kelayang. Penelitian yang dilakukan LIPI menemukan ada beberapa tantangan yang dihadapi dalam pengembangan Kawasan Ekonomi Khusus Tanjung Kelayang, antara lain; jalan tengah sektor pertambangan dan pariwisata, kemampuan APBD untuk membiayai infrastruktur terbatas, nilai tanah yang terus naik, konsentrasi yang tinggi dalam penguasaan lahan, desain backward and forward antara zona KEK dan zona di luar KEK, ketersedian air dan dukungan pemerintah daerah kawasan penyangga KEK masih rendah (CNBC Indonesia, 2018).

Melihat pentingnya dampak yang dapat ditimbulkan oleh kehadiran KEK Tanjung Kelayang terhadap perekonomian lokal khususnya pariwisata. Maka penting untuk mengetahui implementasi yang telah dijalankan oleh para pemangku kepentingan terkait KEK tersebut. Maka tulisan ini akan melihat implementasi KEK Tanjung Kelayang dilihat dari sisi keterlibatan aktor dan faktor-faktor yang mempengaruhinya.

\section{B. METODE PENELITIAN}

Dalam melakukan penelitian mengenai Implementasi Kebijakan Kawasan Ekonomi Khusus Tanjung Kelayang penulis menggunakan pendekatan penelitian secara postpositivist. Penelitian ini menggunakan teori sebagai dasar yang kemudian dibandingkan dengan data-data yang ada di lapangan. Penelitian ini jika dilihat dari tujuan penelitiannya tergolong ke dalam penelitian deskriptif. Penggunaan metode deskriptif ditujukan untuk menggambarkan sifat dari suatu yang sedang berjalan pada saat penelitian sedang dilakukan serta memeriksa penyebab dari suatu gejala tertentu (Travers, 1978 dalam Umar, 2008:87). Maka dalam penelitian ini penelitian deskriptif digunakan untuk menggambarkan implementasi dari kebijakan Kawasan Ekonomi Khusus Tanjung Kelayang secara detil. Novelty atau keterbaruan yang dapat menjadikan penelitian penulis berbeda dari karya ilmiah sebelumnya dapat dilihat dari teori implementasi yang digunakan dan perbedaan lokasi atau studi kasus dari topik pengembangan kawasan pariwisata. Dalam penelitian sebelumnya, implementasi kebijakan pada pemerintah daerah lebih fokus pada kebijakan pangan (Febriyanti dan Juwono, 2017) atau kebijakan pengadaan (Fahillah dan Juwono, 2020).

Penelitian ini termasuk dalam jenis penelitian cross sectional jika dilihat dari dimensi waktu penelitiannya. Penelitian ini dilakukan dalam satu periode, yakni dari bulan Maret hingga Desember 2019. Dalam penelititian ini penulis menggunakan dua teknik pengumpulan data penelitian melalui studi lapangan (data primer) dan studi literatur (data sekunder). Dalam studi lapangan penulis mengumpulkan data melalui wawancara mendalam. Wawancara merupakan interaksi yang dilakukan antara pewawancara dengan narasumber (Babbie, 2010:318). Interaksi tersebut berpusat pada pemberian pertanyaan oleh pewawancara kepada narasumber mengenai topik tertentu, tetapi tidak mengacu pada standar baku tertentu. Penulis melakukan wawancara dengan beberapa pihak yang terkait dengan implementasi KEK, antara lain Sahani Saleh (Wakil Dewan Kawasan Ekonomi Khusus Tanjung Kelayang/Bupati Kabupaten Belitung), Venus (Unit Monitoring dan 
pengawasan, Administrator Kawasan Ekonomi Khusus Tanjung Kelayang), Apriansah (Kepala Seksi Geowisata dan KEK), Dinas Pariwisata Provinsi Bangka Belitung/Sekeretariat Dewan Kawasan KEK Tanjung Kelayang, Baharudin (Kepala Sub Bidang Pariwisata, Kelautan dan Perikanan Bappeda Kabupaten Belitung), Agus M. Taufan (Kepala Dinas PURR Kabupaten Belitung), Ansori (Ketua DPRD Kabupaten Belitung), Adek Julianwar (Koordinator BUPP KEK Tanjung Kelayang), Dayat (Sekretaris LSM Matahati Belitung), dan Yudhi (Akademisi Kebijakan Publik/Akademisi Politeknik Ganesha (Politeknik Pariwisata)). Selanjutnya peneliti juga melakukan studi kepustakaan melalui bahan-bahan referensi yang berupa buku, tulisan ilmiah, jurnal, peraturan, skripsi dan artikel web yang berkaitan dengan implementasi KEK Tanjung Kelayang.

Teknik analisis data kualitatif merupakan suatu proses pengumpulan data, interpretasi dan pelaporan hasil yang dilakukan secara bersama-sama (Cresswell, 2010:274). Penulis dalam penelitian ini menggunakan analisis data kualitatif berdasarkan data yang diperoleh dari studi lapangan dan kepustakaan yang kemudian digunakan untuk melakukan analisis terhadap implementasi kebijakan Kawasan Ekonomi Khusus Tanjung Kelayang. Peneliti membandingkan hasil wawancara dari berbagai narasumber terkait dengan implementasi KEK Tanjung Kelayang yang kemudian dibandingkan dengan data sekunder yang didapat, lalu disusun sesuai dengan runtutan dari kerangka operasional konsep yang sudah dibuat.

Dalam melakukan penelitian berada di Kawasan Ekonomi Khusus Tanjung Kelayang. Lokasi khususnya berada di Kantor Bupati Kabupaten Belitung, Kantor Dinas Pariwisata Provinsi Belitung, Kantor Bappeda Kabupaten Belitung, kantor administrator KEK dan lingkungan kampus Universitas Indonesia.

\section{KERANGKA TEORI}

Menggunakan berbagai definisi yang ada dapat disimpulkan bahwa karakteristik dari kebijakan publik yang mana bukan merupakan tindakan random tetapi disengaja, kebijakan publik berbasis pada tujuan, kebijakan publik dibuat oleh otoritas publik, kebijakan publik terdiri atas pola tindakan, kebijakan publik lahir dari permintaan, tindakan pemerintah untuk menekan suatu masalah dan kebijakan publik dapat bersifat positif atau negatif ( $\underline{\text { Smith \& }}$ Larimer, 2018:3). Berkembangnya sebuah kebijakan publik diawali dari adanya kepercayaan masyarakat mengenai keberadaan sebuah masalah. Terdapat tiga tahapan prakebijakan, yakni: definisi masalah, permintaan kebijakan, dan formasi agenda (Cochran et al., 2015:11). Untuk melakukan analisis terhadap suatu kebijakan, terdapat beberapa aspek yang perlu diperhatikan, antara lain (Dye, 2005 dalam Kusumanegara, 2010:2) perlunya deskripsi atas kebijakan publik yang perlu untuk dianalisis, dengan adanya deskripsi dari kebijakan publik tersebut, dapat dilihat hal-hal yang dilakukan dan tidak dilakukan oleh pemerintah dalam aspek-aspek kehidupan masyarakat seperti pertahanan, kesejahteraan masyarakat, energi, dan pendidikan; diperlukan penelusuran terhadap dasar-dasar atau yang menjadi alasan bagi pemerintah untuk mengeluarkan suatu kebijakan tertentu. Perlu dilihat adanya perbedaan antara aktor yang membuat kebijakan dan keluaran dari kebijakan yang dilakukan. Faktorfaktor mana saja yang mempengaruhi kebijakan tersebut termasuk juga pengaruh aspekaspek sosial, ekonomi, politik dan budaya; perlunya kajian mengenai dampak yang ditimbulkan kebijakan terhadap masyarakat untuk melihat dampak dari suatu kebijakan bagi pihak yang terdampak secara langsung maupun tidak langsung.

Kebijakan publik merupakan sebuah alur proses dari berbagai tahapan yang hingga akhirnya menghasilkan suatu keluaran berupa kebijakan publik dari suatu institusi tertentu. Alur tahapan-tahapan tersebut kemudian membentuk suatu siklus hidup dari kebijakan publik. Dengan mengkaji siklus dari kebijakan publik kita dapat melihat lebih jelas mengenai 
suatu kebijakan publik dari tahap awal hingga akhir dan kembali dari awal. Tahapan-tahapan dari kebijakan publik disebut juga dengan siklus kebijakan.

Proses pembuatan kebijakan publik dapat dibagi menjadi beberapa tahapan. Tahapan tersebut, yaitu agenda setting, formulasi kebijakan, pembuatan kebijakan, implementasi kebijakan, dan evaluasi. Penjelasan lebih lanjut dari setiap tahapan tersebut, antara lain (Howlett \& Ramesh, 2003:131) agenda setting, tahapan ini berlangsung proses menentukan permasalahan-permasalahan publik mana yang perlu dituntaskan. Untuk masuk ke dalam lingkup agenda setting, individu atau kelompok perlu untuk menyatakan bahwa suatu hal tersebut merupakan permasalahan yang genting, membawa solusi dan memberikan tekanan kepada pemerintah untuk turun tangan mengatasi permasalahan tersebut; formulasi kebijakan, tahapan ini berupa para administrator pemerintah melihat dan menimbang alternatif-alternatif solusi dari masalah yang telah diangkat. Pada tahap ini juga muncul aktor-aktor yang memperjuangkan pandangan mereka agar kebijakan yang diambil dapat mengakomodir kepentingannya; pembuatan kebijakan, pada tahapan ini, kebijakan dibentuk oleh level pemerintah yang menghasilkan kebijakan yang mengikuti pendekatan satu atau beberapa pihak; implementasi, tahapan ini berlangsung implementasi dari kebijakan berdasarkan parameter yang telah ditetapkan yang mana akan mempengaruhi hasil akhir dari kebijakan tersebut. Terdapat beberapa faktor yang mempengaruhi, yaitu tipe dan kompleksitas masalah, tingkatan perubahan yang diharapkan pada kelompok target kebijakan, sumber daya manusia dan finansial, dan struktur administrasi dan regulasi; evaluasi, tahapan ini melihat kesesuaian implementasi dengan tujuan yang ingin dicapai. Evaluasi dapat dilakukan oleh aparat pemerintah, konsultan ataupun masyarakat.

\section{Implementasi Kebijakan Publik}

Untuk memahami proses kebijakan diperlukan juga analisis mengenai implementasi kebijakan (Strehlenert et al., 2015:2). Penelitian berkaitan dengan ilmu implementasi kebijakan dan implementasi didasari keinginan untuk memahami, menjelaskan dan menemukan permasalahan berhubungan dalam mengubah intensi implisit dan eksplisit menjadi perubahan yang diinginkan (Nilsen et al., 2013:4). Teori implementasi ditujukan untuk mengembangkan alat konseptual yang kemudian digunakan oleh para praktisi dan peneliti untuk mengidentifikasi, mendeskripsikan, dan menjelaskan unsur penting dalam proses implementasi dan outcome (May, 2013:3).

Untuk memahami proses dari implementasi secara lebih menyeluruh, digunakan teori implementasi yang menggabungkan beberapa teori menjadi suatu kesatuan yang lebih dapat menjelaskan secara menyeluruh mengenai proses implementasi kebijakan. Howlett menggabungkan teori policy cycle model, multiple stream framework dan advocation coalition framework (Howlett, 2018:8-13). Teori ini melihat implementasi melalui interaksi dari berbagai aktor yang mempengaruhi implementasi kebijakaan itu sendiri. Proses tersebut dilihat melalui arus (stream) yang merupakan kejadian atau aktor-aktor tertentu yang saling berinteraksi untuk mempengarui setiap tahap policy circle mulai dari agenda setting hingga evaluasi kebijakan.

Stream pertama yang menjadi acuan dari pergerakan stream lainnya adalah process stream. Process stream yang merupakan basis proses yang membentuk serangkaian tugas dan kejadian menuju output kebijakan melalui setiap rangkaian policy circle. Selanjutnya terdapat empat stream lainnya yang mewakili masing-masing aktor yang berbeda dan akan saling berinteraksi di sepanjang tahapan policy circle yang akan mempengaruhi output dari kebijakan, penjelasan dari setiap stream, antara lain: Problem Stream, arus ini berfokus pada pembentukan dari masalah kebijakan (policy problem) dan serta aktor-aktor yang terlibat 
dalam pendefinisian dari isu-isu kebijakan (Policy issues) (Howlett, 2018:13-17). Pembuatan kebijakan telah menjadi semakin kompleks yang melibatkan berbagai aktor yang berada di lingkaran level dan otoritas yang bervariasi dan tersebar di berbagai tingkatan (Hooghe dan Marks, 2003 dalam Cerna, 2013:11). Aktor-aktor yang mendefinisikan permasalahan kebijakan biasanya terlibat dalam tahapan awal dari pembuatan kebijakan, seperti agenda setting dan formulasi, akan tetapi mereka juga berlanjut dalam implementasi. Aktor-aktor tersebut dapat meliputi ilmuwan, anggota partai dan pihak lainnya yang ikut aktif setelah tahapan agenda setting dan formulasi, yang mana mereka turut serta dalam seminar atau diskusi berkaitan dengan definisi umum maupun khusus dari permasalahan atau isu dari implementasi.

Policy Stream, berbeda pada aktor-aktor sebelumnya yang berurusan pada perumusan permasalahan, aktor-aktor dalam policy stream lebih berfokus pada alat-alat kebijakan (policy tools) dan memberikan para pembuat kebijakan dengan informasi berkaitan dengan desain dan cara kerja dari alat kebijakan tersebut. Aktor-aktor ini terdiri atas berbagai macam pihak seperti akademisi, konsultan kebijakan, kebijakan publik dan administrasi, bisnis, dan masyarakat. Pihak-pihak tersebutlah yang menganjurkan dari alat atau kombinasi dari alatalat yang digunakan untuk mengatasi berbagai macam permasalahan.

Politics Stream, dalam arus ini para aktor-aktor yang terlibat saling berkompetisi satu sama lain agar pilihan dari definisi permasalahan dan juga solusi yang mereka pikirkan dapat diadopsi dan diimplementasikan serta para aktor ini juga ikut aktif sepanjang jalannya implementasi. Para aktor-aktor politik tersebut biasanya lebih terlihat dalam publik dibandingkan dengan aktor-aktor yang lainnya. Mereka dapat berasal dari kepala pemerintah, jajaran pemerintah, anggota dewan, partai politik, ataupun pengikut lain dalam implementasi.

Programme stream, arus ini merupakan yang paling penting dalam tahap implementasi kebijakan. Aktor-aktor yang terlibat dalam arus ini merupakan pihak yang menjalankan implementasi, kebanyakan berupa administrator tetapi bisa juga dari publik atau stakeholder yang terlibat dalam menyampaikan, mendistribusikan atau mengkonsumsi jasa atau barang dari pemerintah. Implementasi kebijakan tentu bertumpu pada para pegawai sipil dan pejabat administratif untuk menjalankan dan mengatur tindakan yang diperlukan. Sebagai kunci dari programme stream, penting bagi para aktor tersebut untuk menggunakan pengetahuan, pengalaman, keahlian dan nilai-nilai yang dimiliki untuk membentuk peluncuran dan evaluasi dari putusan implementasi kebijakan. Birokrat memang merupakan aktor yang paling signifikan dalam sebagian besar implementasi kebijakan dan juga membawa konflik antar maupun didalam agensi publik kedalam tahapan implementasi. Agensi birokrasi yang berbeda dalam berbagai level pemerintahan biasanya dalam proses implementasi membawa kepentingan tertentu, ambisi dan tradisi yang dapat mempengaruhi proses implementasi dan dampak (outcome) yang ditimbulkannya. Aktor yang berasal dari luar pemerintahan yang juga termasuk ke dalam bagian dari subsistem kebijakan juga dapat ikut terlibat dalam aktivitas implementasi yang berlangsung seperti melalui produksi bersama atau kerjasama pelayanan jasa.

Penting untuk memahami implementasi kebijakan karena implementasi merupakan tahapan kunci dari suatu proses kebijakan dan dengan memahami mengenai permasalahan dalam implementasi akan meningkatkan kemampuan untuk mengembangkan struktur kebijakan yang menjamin tercapainya tujuan dari kebijakan yang dibuat (Birkland, 2015:177). Performa dari suatu implementasi kebijakan dapat dikategorikan ke dalam tiga area, yaitu output dan outcome dari kebijakan, dampak dari kebijakan, dan penilaian terhadap kebijakan apakah sudah berdampak pada pengembangan negara atau masyarakat secara keseluruhan. Untuk mencapai keberhasilan outcome kebijakan tidak hanya 
bergantung pada pengembangan sistem yang efektif tetapi juga bergantung pada pengelolaan dari implementasi kebijakan tersebut (Khan \& Khandaker, 2016:541). Dalam proses implementasi kebijakan dapat dipengaruhi oleh beberapa variabel yang dapat menentukan performa dari implementasi kebijakan tersebut. Dalam perkembangannya muncul beberapa teori model implemenentasi kebijakan.

Model biasanya melibatkan penyederhanaan dari suatu fenomena atau aspek dari fenomena (Nilsen, 2015:2). Salah satu model yang dibuat yaitu oleh Van Meter dan Van Horn dalam Agustino (2012:142) yang menjabarkan enam variabel yang mempengaruhi implementasi kebijakan publik, antara lain ukuran dan tujuan kebijakan, sumber daya, karakteristik agen pelaksana, sikap pelaksana, komunikasi antar organisasi dan aktivitas pelaksana dan lingkungan ekonomi, sosial dan politik. Model implementasi lain juga dikembangkan oleh Edward III dalam Winarno (2007:144) yang memasukkan variabel kesuksesan dari suatu implementasi kebijakan kedalam empat variabel antara lain: komunikasi, sumber daya, disposisi dan struktur birokrasi. Lebih lanjut Khan \& Khandaker (2016:542-543) membuat model yakni rational model. Rational model berisikan indikatorindikator yang mana memiliki pengaruh terhadap performa atau kinerja dari implementasi kebijakan.

Rational Model dibuat berdasarkan asumsi bahwa implementasi kebijakan memerlukan kejelasan antara tujuan, misi dan objektif, perencanaan yang akurat dan konsisten, pembagian tugas yang jelas, pengawasan yang memadai, dan standarisasi yang terukur. Dengan dilaksanakannya indikator-indikator tersebut maka akan meningkatkan performa dari implementasi kebijakan begitu juga sebaliknya (Khan \& Khandaker, 2016:542).

\section{HASIL DAN PEMBAHASAN}

Penelitian ini membahas mengenai implementasi kebijakan kawasan ekonomi khusus menggunakan teori implementasi Howlett yang melihat implementasi berdasarkan keterlibatan aktor-aktor dalam proses implementasi. Pada implementasi kebijakan kawasan ekonomi khusus melibatkan berbagai aktor. Kebijakan didasari atas kesempatan usaha bagi konsorsium pengelola KEK dalam melakukan usahanya agar mendapat insentif dari Pemerintah. Sedangkan Pemerintah Daerah melihat KEK sebagai kesempatan dalam melakukan pengembangan potensi pariwisata kawasan. Permasalahan yang dihadapi KEK antara lain kurangnya pengembangan aktraksi wisata lokal selain pantai dan tidak adanya penerbangan langsung dari luar negeri yang membuat investor wait and see dalam menanamkan modal.

Untuk membahas faktor-faktor implementasi menggunakan teori model rasional Khan dan Khandaker untuk melihat faktor-faktor yang berpengaruh dalam implementasi. Hasilnya terlihat bahwa terdapat beberapa faktor yang mempengarui hasil implementasi yakni ketiadaan visi dan misi yang jelas, perencanaan dalam target investasi yang kurang dan pengawasan yang tidak memiliki wewenang intervensi.

\section{Proses Implementasi Kebijakan Pengembangan Kawasan Ekonomi Khusus Tanjung Kelayang}

Pembahasan ini untuk menjawab tujuan penelitian pertama, yaitu untuk menganalisis implementasi kebijakan pengembangan KEK Tanjung Kelayang menggunakan teori Howlett yang memiliki empat indikator, yaitu Problem Stream, Policy Stream, Politic Stream dan Programme Stream. Pada indikator pertama membahas mengenai problem stream. Dilihat dari isu atau masalah yang memunculkan kebijakan KEK Tanjung Kelayang, 
kebijakan ini upaya pemerintah dalam mengembangkan pariwisata daerah khususnya Kabupaten Belitung dengan cara memberikan kemudahan dalam hal perizinan, insentif dan bantuan pendukung bagi badan usaha dalam hal ini konsorsium swasta untuk dapat melakukan usahanya di kawasan yang sudah ditentukan yaitu KEK Tanjung Kelayang. Badan Usaha Swasta (menjadi BUPP) tersebut yang juga merupakan pihak yang mengajukan KEK Tanjung Kelayang melihat potensi kesempatan untuk melakukan usaha dengan insentif dari pemerintah, hal tersebut dinyatakan oleh Adek Julianwar (Koordinator BUPP KEK Tanjung Kelayang).

"Pertimbangan pengajuannya banyak, karena kalau punya KEK itu kalau ditetapkan jadi KEK mereka akan berikan kemudahan atau keringanan melakukan usaha ekonomi tadi. Itu tergantung dari pertimbangan yang mengusulkan. Pertimbangan kita, kita ingin majukan kawasan Belitung dan kita punya lahan disitu dan untuk mengembangkan itu kita ingin dapat keringanan dan insentif dari pemerintah." (wawancara dengan Adek Julianwar Koordinator BUPP KEK Tanjung Kelayang, 2 desember 2019)

Pemerintah melihat kebijakan ini sebagai suatu cara pengembangan potensi pariwisata daerah untuk melangkah dari perekonomian berbasis tambang, hal ini dapat dilihat dari pernyataan Ansori (Ketua DPRD Kabupaten Belitung).

"Kita melakukan studi-studi ke Banten, kunjungan kerja lah. Tanjung Lesung. Semua anggota kita libatkan kesana. Untuk melihat oh seperti ini rintisan KEK itu seperti ini. Kita sudah sepakat bahwa Belitung ini cuma satunya wisata yang akan kita perkuat unggulannya karena kita sudah mikir Belitung kan sudah timah nah pasca timah ini kita ke wisata nah wisata ini harus ekonomi khusus agar ada lah perhatian dari pusat daripada kita ngandalkan APBD sendiri." (wawancara dengan Ansori Ketua DPRD Kabupaten Belitung, 25 November 2019)

Di sisi implementasi kebijakan melalui Problem Stream juga dilihat permasalahan yang melanda implementasi kebijakannya. Dalam hal ini beberapa masalah yang melanda implementasi dari KEK bermuara pada sikap investor yang wait and see dalam melakukan investasi, pernyataan tersebut disampaikan oleh Venus (Administrator Kawasan Ekonomi Khusus).

"Masalah realisasi, investor itu masalah sedikit investasi disitu, itu kan besar investasinya jadi investor nunggu dulu, bagaimana investor yang pertama suksesnya. Tingkat huniannya, okupansinya, seberapa banyak jadi mereka prospek bisnisnyalah untuk disitu, jadi mereka wait and see dulu nah ini nunggu dulu yang sheraton dulu. Kalo prospek bisnisnya bagus, baru mereka masuk." (wawancara dengan Venus Administrator Kawasan Ekonomi Khusus, 8 November 2019)

Hal ini disebabkan oleh kurangnya pengembangan atraksi-atraksi wisata di Kabupaten Belitung. Sebagian besar wisata di Kabupaten Belitung masih mengandalkan wisata baharinya berupa pantai-pantai di sepanjang pesisir pulau, sedangkan atraksi-atraksi wisata lain khususnya di desa-desa sekitar kurang digali oleh pemerintah daerah. Hal ini 
mengakibatkan kurangnya daya tarik Kabupaten Belitung bagi wisatawan dibandingkan dengan destinasi wisata daerah lain yang secara objek wisata lebih lengkap, hal ini didukung oleh pernyataan dari Adek Julianwar (Koordinator BUPP KEK Tanjung Kelayang).

"Jadi mesti ada daya tarik. Itulah kita minta tolong ke pemerintah. Atraksi Belitung apa sih? Di belitung apa sih ngopikan, ga ada lagi. Jika di Belitung tidak ada pesawat langsung dari Singapur siapa yang mau datang. Pelaku ekonomi yang mikir ke situ. Makanya saya bilang bisa ga setiap desa ada makanan khas, setiap desa ada kesenian khas, dipilih nanti yang menonjol itu yang ditonjolin jadi semua desa yang 46 itu ada objek wisatanya karena ga akan jalan kalo ga ada ini. Orang ke pantai ngapain sih orang semua pantai di Indonesia kayak gitu semua kok." (wawancara dengan Adek Julianwar Koordinator BUPP KEK Tanjung Kelayang, 2 desember 2019)

Pemerintah daerah dalam hal ini kurang melakukan pengembangan terhadap desa-desa atau kearifan lokal yang ada. Padahal pemerintah daerah bisa membantu desa-desa tersebut memunculkan keunikannya masing-masing sehingga dapat dijadikan atraksi wisata yang menarik bagi wisatawan. Selain kurangnya atraksi wisata selain pantai, permasalahan lainnya yaitu tidak adanya akses langsung penerbangan dari luar negeri menuju ke Kabupaten Belitung. Mengingat lokasi Kabupaten Belitung yang merupakan kepulauan maka penting adanya akses udara dari dan menuju lokasi khususnya dari negara asing yang merupakan domisili dari wisatawan yang merupakan target dari pariwisata Kabupaten Belitung. Hal ini dinyatakan oleh Adek Julianwar (Koordinator BUPP KEK Tanjung Kelayang).

"Orang liat perkembangan datang ga orang ke Belitung itu dulu. Anda ngarepin orang dari Singapore ke Belitung lewat Jakarta ya engga lah ga bakal ke Belitung orang. Jadi ada aspek pariwisata tadi akses, amenitas dan atraksi kalo itu ga ada orang ga bakal ke Belitung kok itu dulu yang mesti disiapkan aksesnya ada gak, penerbangan langsungnya ada gak mati hidupkan.” (wawancara dengan Adek Julianwar Koordinator BUPP KEK Tanjung Kelayang, 2 desember 2019)

Ketidakadaan akses tentu akan mempersulit wisatawan asing untuk melakukan perjalanan menuju Kabupaten Belitung. Dua permasalahan tersebut akan berdampak langsung kepada kurangnya minat dan realisasi kunjungan wisatawan ke Kabupaten Belitung yang berpengaruh terhadap minat investor dalam berinvestasi.

Pada tahapan pembuatan kebijakan biasanya terdapat pihak-pihak yang membantu para pemangku kebijakan dengan memberikan pengetahuan atau informasi berkaitan dengan alat yang digunakan sebagai solusi bagi masalah kebijakan (policy problem). Analisis ini akan melihat aktor-aktor yang terlibat dalam proses tersebut. Untuk KEK Tanjung Kelayang BUPP yang dulu juga bertindak sebagai pengaju KEK memilih untuk melakukan kegiatankegiatan berkaitan dengan pemenuhan syarat pengajuan KEK secara mandiri tanpa melibatkan pihak lain baik akademisi maupun konsultan. Hal tersebut dinyatakan oleh Adek Julianwar (Koordinator BUPP KEK Tanjung).

"Tidak pernah minta bantuan siapa-siapa sendiri aja, kita ga nyari konsultan, kita sendiri aja kita baca peraturan lengkapi semuanya. Memang ada yang 
nawarin perlu konsultan ga, tapi engga ah.“ (wawancara dengan Adek Julianwar (Koordinator BUPP KEK Tanjung Kelayang, 2 desember 2019)

Indikator selanjutnya merupakan Politic Stream yang melihat aktor-aktor yang memiliki kepentingan di dalam proses implementasi KEK Tanjung Kelayang. Tiap-tiap aktor memiliki kepentingan yang mereka perjuangkan agar masuk kedalam proses implementasi. Terdapat beberapa aktor yakni LSM, DPRD Kabupaten Belitung dan Akademisi. LSM memperjuangkan agar KEK dapat membawa kearifan lokal Belitung dalam penerapannya memberdayakan warga-warga dan atraksi-atraksi lokal. Hal tersebut disampaikan oleh Dayat (Sekretaris LSM Matahati Bangka Belitung).

"Kearifan lokal, dalam artian okelah tenaga teknis profesional mereka narik dari luar tapi disinikan ada SMK pariwisata, berdayakan warga-warga dan juga konten-konten lokal jangan dilupakan juga kesenian lokalnya harus ada. Paling tidak penampilan kesenian lokal itu akan menghidupkan sanggarsanggar seni yang ada agar mereka tetap punya job dan kesenian terus bergulir... Hari ini yang saya liat sheraton mau membuka lapangan pekerjaan dan alhamdulillah sheraton kooperatif dalam hal ini dia testnya juga dibelitungkan. Paling tidak mereka sudah mau memberdayakan konten lokal. Kita sudah sampaikan hal ini ke pemerintah dan KEKnya." (wawancara dengan Dayat Sekretaris LSM Matahati Bangka Belitung, 21 November 2019)

Hal tersebut dimaksudkan agar dengan adanya KEK dapat menghidupi sanggarsanggar kesenian yang ada di Kabupaten Belitung melalui pembukaan lapangan pekerjaan di dalam KEK. DPRD memperjuangkan agar KEK dapat berdampak pada masyarakat khususnya dampak ekonomi kepada masyarakat. Selain perlu juga lokalisasi terhadap UMKM agar dapat tertib dalam berjualan. Kepentingan yang dibawa oleh dua pihak lebih menitikberatkan pada pemberdayaan masyarakat lokal sehingga dapat merasakan dampak dari adanya KEK tersebut khususnya dari sisi ekonomi. Hal ini didapat dari pernyataan Ansori (Ketua DPRD Kabupaten Belitung).

"Kita harapkan berdampak ke masyarakat itu, dalam arti kata UMKM nya daya belinya, kita harapkan efek masyarakat ini dalam ekonominya. Masyarakat UMKM minta dilokalisasi biar tidak bertebaran di sana sini. Terus kita serahkan ke Pemda." (wawancara dengan Ansori Ketua DPRD Kabupaten Belitung, 25 November 2019)

Akademisi setempat mengharapkan dalam proses implementasi KEK agar dapat dijalankan menjadi kawasan ekonomi khusus sesungguhnya yang mampu mempermudah investasi bagi para investor hal itu dikarenakan sudah dipenuhinya insentif berupa pajak dari pemerintah dan juga pembangunan sarana-prasarana pendukung KEK. Hal ini terlihat dari pernyataan Yudha (Akademisi Politeknik Ganesha).

"Kita ingin daerah Kek itu benar-benar menjadi daerah KEK yang sebenarnya. Itu kan daerah Ekonomi Khusus. Sehingga investor emang bener-bener bisa berinvestasi menguntungkan bagi mereka. Pajak mereka ditekan kan. Selain itu area itu untilitasnya udah terjamin infrastrukturnya 
air, listrik dibangun segala macam”. (wawancara dengan Yudha Akademisi Politeknik Ganesha, 22 November 2019)

Indikator selanjutnya, yaitu Programme Stream yang digunakan untuk melihat keterlibatan aktor-aktor yang bertindak sebagai implementator dalam implementasi. BUPP merupakan pihak yang bertugas menyiapkan dan mengelola kawasan di dalam KEK agar siap pakai. Siap pakai artinya dapat siap dimasuki oleh investor untuk menanamkan modal. Sesuai dengan Peraturan Pemerintah Nomor 2 Tahun 2011 Tentang Penyelenggaraan Kawasan Ekonomi Khusus, yang mana mengamanatkan pembangunan kawasan kepada badan usaha yang mengajukan KEK yakni konsorsium PT Belitung Maritime yang merupakan BUPP dari KEK Tanjung Kelayang.

Aktor lainnya, yaitu administrator KEK dalam hal ini sebagai pihak yang mengurus perizinan, pengelolaan, dan evaluasi serta laporan yang berkaitan dengan KEK Tanjung Kelayang. Hal tersebut sesuai dengan tugas administrator KEK yang terdapat dalam Peraturan Gubernur Nomor 21 Tahun 2017 Tentang Penetapan Dinas Penanaman Modal, Pelayanan Terpadu Satu Pintu dan Perindustrian Kabupaten Belitung Sebagai Administrator Kawasan Ekonomi Khusus Tanjung Kelayang, pada pasal 5 yang menyatakan tugas administrator KEK berkaitan dengan tiga hal, yaitu: (1) pemberian izin usaha dan izin lain yang diperlukan pelaku usaha yang mendirikan, menjalankan, dan mengembangkan usaha KEK; (2) melakukan pemantauan dan pengendalian operasional KEK; dan (3) menyampaikan laporan operasionalisasi KEK secara berkala dan/atau secara insidental kepada Dewan Kawasan Ekonomi Khusus Provinsi Bangka Belitung. Selain itu terdapat Sekretariat Dewan Kawasan yang ketelibatannya adalah melakukan promosi-promosi berkaitan dengan KEK kepada para pihak-pihak terkait. Selain itu, Sekretaris Dewan Kawasan juga bertugas dalam melakukan integrasi terhadap sektor sektor terkait dengan implementasi KEK. Hal ini dinyatakan oleh Apriansah (Kepala Seksi Geo Wisata dan Kawasan Ekonomi Khusus Dinas Pariwisata Sekretariat Dewan Kawasan).

"Peran pemerintah ini melakukan promosi pengembangan promosi KEK, itu bentuk support pemerintah untuk cepat agar investor tau kalau Belitung punya KEK. Kami besok ke Surabaya dalam rangka promosikan KEK. Kami tugasnya mengintegrasikan sektor terkait." (wawancara dengan Apriansah Kepala Seksi Geo Wisata dan Kawasan Ekonomi Khusus Dinas Pariwisata Sekretariat Dewan Kawasan, 29 Oktober 2019)

Selanjutnya keterlibatan Bappeda adalah sebagai jembatan dalam perencanaan pembangunan infrastruktur penunjang di luar kawasan KEK. Peran Bappeda dalam ini juga mengajukan anggaran kepada instansi terkait untuk proses pembangunan infrastruktur penunjang tersebut. Hal ini dijelaskan oleh Baharudin (Kasubdit Keuangan, Pariwisata dan Perikanan Bappeda).

"Kalau kita di Bappeda memfasilitasinya dengan kegiatan yang ada di pemerintah, misal pembangunan jalan yang ada di Bappeda. Misal membutuhkan anggaran ke pusat maka Bappeda mengusulkan ke Kementerian pusat lewat Kementerian PU, demikian juga air bersih, telekomunikasi, listrik. Usulan tersebut melalui anggaran pemerintah lewat Bappeda sesuai dengan APBN, APBD provinsi maupun APBD kabupaten." 
(wawancara dengan Baharudin Kasubdit Keuangan, Pariwisata dan Perikanan Bappeda, 29 oktober 2019)

\section{Faktor-faktor yang berpengaruh terhadap implementasi Kawasan Ekonomis Khusus Tanjung Kelayang}

Indikator pertama berupa kejelasan visi dan misi dalam hal ini pengimplementasian dari sisi pemerintah tidak memiliki visi, misi khusus yang terstruktur jelas hanya berbasis dari visi misi Bupati dan Wakil Bupati yang dalam visi, misi di RPJMD nya tidak secara khusus memasukkan pengembangan KEK. Hal ini dinyatakan oleh Venus (Administrator Kawasan Ekonomi Khusus).

"Kalau visi misi kita ga ada tapi kalau pengelola KEK nya BUPP dia mungkin ada visi, misinya. Di KEK itu ada badan usaha pembangunan dan pengelola KEK itu, KEK kita kan KEK yang swasta itu ... Namanya visi kita ga ada, adanya visi kita visi bupati Wakil Bupati itu. Pengembangan ekonomi itu berbasis potensi daerah artinya di sektor pariwisata. Kita mendukungnya dalam bentuk membuat iklim yang kondusif gitu." (wawancara dengan Venus Administrator Kawasan Ekonomi Khusus, 8 November 2019)

Sedangkan Pihak BUPP selaku pengelola KEK memiliki visi, misi dan target namun belum jelas penjabarannya. Hal ini disampaikan oleh Adek Julianwar (Koordinator BUPP KEK Tanjung Kelayang).

"Mewujudkan kawasan pariwisata itu sesederhana itu, misinya ya kita bangun lokasi itu mengajak investor masuk dan segala macem.... Visinya menjadikan kawasan sebagai ecotourism yang cinta lingkungan, misinya ya berkaitan implementasi. Cinta lingkungan diwujudkan dengan tidak memotong pohon-pohon itu dulu. Terus kayunya digunakan menggunakan kearifan lokal." (wawancara dengan Adek Julianwar Koordinator BUPP KEK Tanjung Kelayang, 2 desember 2019)

Indikator Kedua, yaitu perencanaan yang konsisten, pemerintah ataupun BUPP memiliki perencanaan dalam melakukan implementasi pengembangan KEK Tanjung Kelayang. Sebagian besar dari target-target yang telah ditetapkan dalam perencanaan sudah terselesaikan pada waktunya. Walaupun sebagian fasilitas pendukung berupa air belum selesai. Hal ini disampaikan oleh Baharudin (Kasubdit Keuangan, pariwisata dan perikanan Bappeda).

"Jalan, air, drainase kemudian listrik. Itukan yang dasar-dasar dulu. Kemudian PLN sudah siap memenuhi kebutuhan. Kemudian telekomunikasi, mereka memperkuat sinyal di sekitar kek. Pada umumnya support pemerintah sudah kecuali air minum mengenai tempat penampungan dan supply. Tapi tahun ini sudah berjalan. Seperti dari SPAM Sijuk sampai ke lokasi KEK. Tahun depan dilanjutkan sampai ke Tanjung Binga, berarti melewati lokasi KEK. Lalu di dalam KEK yang masih proses pembangunan hotel, Hotel Sheraton udah hampir jadi." (wawancara dengan Baharudin Kasubdit Keuangan, Pariwisata dan Perikanan Bappeda, 29 oktober 2019) 
Berkaitan dengan fasilitas pendukung yang ada di dalam KEK, yaitu pengadaan tanah, sertifikasi, pematangan lahan, jalan kawasan, listrik, instalasi dan jaringan air bersih, sistem air limbah, drainase, gerbang dan batas kawasan, telekomunikasi, persampahan, pemadam kebakaran, kantor administrator, dan pengelola sudah semua dipenuhi oleh BUPP akan tetapi untuk target investasi masih belum terpenuhi (Belitung Maritime Ecotourism Development, 2019:5-6). Selain itu, belum adanya kelanjutan dari MOU yang dilakukan sebelumnya terkait dengan investasi China Harbour dan Hotel Sofitel yang mana masing-masing berkomitmen memasukan investasi sebesar \$ 1 miliar dan Rp400 miliar (Dewan Nasional Ekonomi Khusus Republik Indonesia, 2017). Akan tetapi, belum ada kelanjutan dari MOU tersebut.

Melihat dari hal tersebut terlihat bahwa dalam perencanaan terdapat masalah, yaitu realisasi investasi yang masih jauh di bawah ekspektasi atau target investasi. Hal ini karena dalam penyusunan perencanaan khususnya target investasi kurang memerhatikan faktorfaktor seperti kelemahan dalam pariwisata di Kabupaten Belitung yang diakui oleh BUPP merupakan salah satu masalah kendala dalam investasi yang dijelaskan dalam analisis Problem Stream yakni kurangnya daya tarik keunikan-keunikan daerah selain pantai yang dikembangkan oleh pemerintah daerah sehingga pariwisata Kabupaten Belitung hanya bertumpu pada wisata berbasis pantai saja sedangkan potensi-potensi di desa-desa yang dapat dijadikan destinasi wisata kurang mendapat pengembangan dari Pemerintah Daerah. Selain itu, kurangnya akses penerbangan dari luar negeri juga tidak dimasukkan ke dalam faktor perencanaan oleh BUPP. Kedua hal tersebut mengakibatkan investor menjadi menunggu dalam melakukan investasinya. Dalam hal ini perencanaan memasukan target investasi yang terlalu besar di awal yang secara kondisi di lapangan sulit untuk direalisasikan.

Indikator Ketiga, yaitu pembagian tugas yang jelas, setiap aktor implementasi memiliki tugasnya masing-masing sesuai dengan kebutuhan dari implementasi. Dalam implementasi KEK Tanjung Kelayang terdapat perbedaan antara kewajiban dari pemerintah daerah dan BUPP. Pemerintah daerah dalam hal ini ditugaskan untuk melakukan pembangunan fasilitas penunjang yang berada di luar KEK. Dalam hal ini pemerintah hanya membangun insfrastruktur hingga pintu depan KEK saja. Sedangkan urusan pembangunan di dalam KEK menjadi urusan dari BUPP selaku pengelola KEK. Hal ini disampaikan oleh Apriansah (Kepala Seksi Geo Wisata dan Kawasan Ekonomi Khusus Dinas Pariwisata Sekretariat dewan kawasan).

"Pemerintah itu mengantarkan sampai dengan gerbang kawasan, misal jaringan telekomunikasi, kami cuma sampai gerbang depan. Untuk masuk ke dalam kawasan ekonomi khusus sudah menjadi tanggung jawab BUPP. Begitu juga dengan jaringan air dari PAM yang dikembangkan PUPR itu dihantarkan sampai depan gerbang KEK. Untuk Kawasan 300 hektar di dalam menjadi tanggung jawab BUPP." (wawancara dengan Apriansah Kepala Seksi Geo Wisata dan Kawasan Ekonomi Khusus Dinas Pariwisata Sekretariat dewan kawasan, 29 Oktober 2019)

Indikator Keempat, yaitu adanya standarisasi, pemerintah daerah beserta jajaran dan juga NUPP menggunakan standar operasional (SOP) dari tiap-tiap instansi dalam melakukan implementasi KEK Tanjung Kelayang. Hal ini dibenarkan oleh Venus (Administrator Kawasan Ekonomi Khusus, 8 November 2019): "Standar kan sama saja seperti SOP (standar operasional) nya ada sama aja, SOP standar pelayanan ada, di dinas PTSP pasti ada itu. Tidak ada dibikin khusus jadi mengikuti standar dari dinas." Selain itu juga terdapat standarisasi 
pelayanan minimal pengelolaan destinasi berbasis geowisata yang dimiliki oleh Dinas Kebudayaan dan Pariwisata Provinsi Bangka Belitung. Hal ini mengatur pengelolaan kelembagan dan sumber daya manusia, pengelolaan sarana dan prasarana, pengelolaan atraksi/daya tarik wisata, pemberdayaan masyarakat dan edukasi, mitigasi bencana dan rencana evakuasi, pengelolaan keamanan dan keselamatan wisatawan, pengelolaan keruangan, konservasi, dan pelestarian; dan pengelolaan pengunjung.

Indikator Kelima, yaitu adanya pengawasan yang memadai, dalam hal ini pengawasan dan evaluasi terhadap implementasi KEK sudah dilakukan secara rutin oleh beberapa lembaga negara antara lain KPK, BPK, BPKP, administrator KEK, dan administrator. Pengawasan dilakukan terhadap rencana pengembangan kawasan yang telah dibuat oleh pengelola KEK serta realisasi dari penanaman modal investor. Ketika muncul kendala bagi para investor atau pengelola maka akan dilakukan pengembangan lebih lanjut guna mencari solusi permasalahannya. Akan tetapi, pengawasan yang dilakukan tidak dapat langsung mengintervensi kepada pengelola KEK tapi hanya lewat surat ke Kementerian Perekonomian. Hal ini disampaikan oleh Apriansah (Kepala Seksi Geo Wisata dan Kawasan Ekonomi Khusus Dinas Pariwisata Sekretariat dewan kawasan).

"Kami melakukan pengawasan terhadap pengembangan dan pengelolaan dalam KEK tetapi kami juga tidak bisa melakukan intervensi. Paling kalau misalnya mereka kurang greget nanti kami kumpulkan administrator, BUPP dan sektor-sektor terkait. Apa sih yang menjadi kendala dalam KEK sehingga mandek atau percepatannya kurang. Mereka sampaikan tapikan sifatnya investasi. Jadi kami memastikan apakah BUPP itu berjalan sudah sesuai dengan masterplannya....... Jika hasil pengawasan tidak sesuai standar, kami tidak bisa ngapa-ngapain juga kami paling cuma bikin laporan ke Menko Perekonomian." (wawancara dengan Apriansah Kepala Seksi Geo Wisata dan Kawasan Ekonomi Khusus Dinas Pariwisata Sekretariat dewan kawasan, 29 Oktober 2019)

Tabel 1.

Hasil Penelitian

\begin{tabular}{ll}
\hline Indikator & Hasil Penelitian \\
\hline Problem Stream & KEK Tanjung Kelayang merupakan inisiatif yang dilakukan oleh BUPP \\
& untuk mendapatkan insentif dari pemerintah dalam melakukan kegiatan \\
& usaha yang dilihat oleh pemerintah daerah sebagai suatu hal yang dapat \\
& mengembangkan pariwisata yang sudah ada di Kabupaten Belitung. \\
& Permasalahan dalam implementasi KEK berupa lambatnya realisasi \\
& investasi yang disebabkan investor memilih untuk wait and see, selain itu \\
& kurangnya akses penerbangan mancanegara langsung ke Kabupaten \\
& Belitung dan kurangnya atraksi wisata menarik mempengaruhi minat \\
& wisatawan datang ke Belitung yang berdampak pada minat investor untuk \\
& menanamkan modalnya. \\
& Dalam pengajuan KEK Tanjung Kelayang, BUPP melakukan prosesnya \\
& bersama dengan pemerintah daerah tanpa melibatkan akademisi atau \\
& konsultan. \\
Policy Streamentingan yang ingin dicapai adalah Keberhasilan KEK dalam \\
Politic Stream \\
memudahkan investasi para investor dan agar KEK mau merangkul \\
kearifan lokal dan masyarakat sekitar sehingga masyarakat mendapat
\end{tabular}




\begin{tabular}{|c|c|}
\hline Indl & Hasil Penelitian \\
\hline & $\begin{array}{l}\text { dampak KEK khususnya di bidang ekonomi dapat dirasakan oleh } \\
\text { masyarakat luas. }\end{array}$ \\
\hline & Implementasi dilakukan oleh banyak aktor, antara lain dari pemerintah \\
\hline & $\begin{array}{l}\text { daerah yang bertugas melakukan pembangunan infrastruktur di luar KEK, } \\
\text { perencanaan, perizininan, pengawasan terhadap KEK dan BUPP yang } \\
\text { bertugas dalam melakukan pengelolaan dan pembangunan dalam KEK. }\end{array}$ \\
\hline Kejelasan dari & Keberadaan visi dan misi yang jelas kurang terpenuhi karena secara \\
\hline $\begin{array}{l}\text { visi, misi dan } \\
\text { target }\end{array}$ & $\begin{array}{l}\text { khusus pemerintah daerah tidak memiliki visi misi bersama yang } \\
\text { dijadikan sebagai patokan implementasi, sedangkan BUPP memiliki visi } \\
\text { dan misi tetapi tidak dibuka untuk publik. }\end{array}$ \\
\hline $\begin{array}{l}\text { Perencanaan } \\
\text { yang akurat dan } \\
\text { konsisten }\end{array}$ & $\begin{array}{l}\text { Pemerintah daerah dan BUPP sama-sama memiliki perencaan y } \\
\text { dalam pembangunan dan pengembangan KEK serta sebagi } \\
\text { targetnya sudah dipenuhi kecuali target investasi yang belum } \\
\text { yang disebabkan kurang diperhitungkannya faktor hambata } \\
\text { pariwisata Kabupaten Belitung dalam penyusunan target investa }\end{array}$ \\
\hline $\begin{array}{l}\text { Pembagian } \\
\text { tugas yang jelas }\end{array}$ & $\begin{array}{l}\text { Terdapat pembagian tugas yang jelas dalam implementasi KEK. Dalam } \\
\text { hal ini porsi tugas dan wewenang antara jajaran pemerintah daerah dan } \\
\text { BUPP sudah jelas. }\end{array}$ \\
\hline Standarisasi & $\begin{array}{l}\text { Standardisasi yang diterapkan dalam bentuk standar operasional yang ada } \\
\text { di administrator KEK dan BUPP KEK, selain itu juga terdapat } \\
\text { standardisasi dalam bentuk pedoman pelayanan minimal destinasi } \\
\text { berbasis geowisata. }\end{array}$ \\
\hline $\begin{array}{l}\text { Pengawasan } \\
\text { yang memadai }\end{array}$ & $\begin{array}{l}\text { Pengawasan yang dilakukan melalui beberapa instansi pemerintah, akan } \\
\text { tetapi pengawas dari pemerintah daerah tidak dapat melakukan intervensi } \\
\text { langsung. }\end{array}$ \\
\hline
\end{tabular}

Sumber: Olahan Penulis

\section{E. PENUTUP}

Berdasarkan hasil analisis dapat dilihat proses implemetasi KEK Tanjung Kelayang yang merupakan usaha pemerintah dalam mengembangkan potensi pariwisata daerah Kabupaten Belitung dengan cara memberikan kemudahan dalam perizinan dan insentif serta fasilitas penunjang bagi badan swasta agar kegiatan usaha khususnya di bidang pariwisata dapat berkembang. Dilihat dari keterlibatan aktor-aktor terkait implementasi KEK Tanjung Kelayang didasari oleh BUPP untuk mengembangkan kawasan di Kabupaten Belitung agar mendapat insentif melakukan usaha dari pemerintah. Pemerintah daerah mendukung hal tersebut sebagai suatu hal yang dapat mengembangkan potensi pariwisata Kabupaten Belitung sejalan dengan harapan masyarakat. Implementasi KEK dilakukan melalui BUPP sebagai pihak yang melakukan pembangunan dan pengelolaan kawasan di dalam KEK, sedangkan pemerintah daerah sebagai pihak yang membangun infrastruktur pendukung diluar KEK. Selain itu juga memberikan perizinan dan pengawasan terhadap jalannya implementasi. Permasalahan dalam KEK adalah lambatnya realisasi investasi yang disebabkan oleh faktor wait and see dari pelaku investor yang menunggu keberhasilan investasi pertama KEK, sikap investor diakibatkan dari kurangnya atraksi atau daya tarik wisata Kabupaten Belitung yang lebih mengandalkan daya tarik pantainya saja dan juga kurangnya fasilitas penerbangan langsung dari mancanegara ke Kabupaten Belitung. Kedua hal tersebut berdampak pada kurangnya wisatawan yang datang khususnya wistawan asing. 
Berkaitan dengan faktor-faktor yang mempengaruhi implementasi KEK, yaitu (1) tidak adanya visi misi yang jelas dari sisi pemerintah dalam implementasi KEK; (2) Sudah terdapat perencanaan yang akurat dan dijalankan dengan konsisten oleh aktor-aktor implementasi KEK diliat dari ketercapaian target dari perencanaan yang sudah dibuat oleh masing-masing aktor kecuali kurangnya perencanaan dalam hal target realisasi investasi yang disebabkan kurang memasukkan faktor masalah atau hambatan dalam pariwisata Kabupaten Belitung, yaitu kurangnya atraksi wisata selain pantai dan tidak adanya penerbangan langsung dari luar negeri; (3) sudah terdapat pembagian tugas yang jelas dalam implementasi KEK dilihat dari tugas dari masing-masing aktor yang sesuai sektornya masing-masing; (4) terdapat juga standardisasi yang terukur melalui SOP dan pedoman pelayanan minimal pengelolaan destinasi berbasis geowisata; dan (5) sudah ada pengawasan yang memadai berkenaan dengan implementasi walau masih kurang dalam sisi intervensi yang dapat dilakukan oleh instansi pengawas.

Pemerintah daerah sebaiknya lebih meningkatkan pengembangan atraksi-atraksi wisata di desa-desa dengan mencari keunikan dari masing-masing desa-desa yang ada di Kabupaten Belitung agar Kabupaten Belitung memiliki daya tarik lain selain dari pantai serta pemerintah daerah mengembangkan masyarakat agar sadar pariwisata yang mana masyarakat memiliki kemampuan dalam mempersiapkan diri untuk Kabupaten Belitung menjadi destinasi wisata KEK. Hal ini dapat dilakukan melalui pendanaan dan pelatihan kepada desa-desa dengan potensi wisata.

Pemerintah perlu meningkatkan aksesibilitas khususnya dalam jalur udara agar ke dan dari Kabupaten Belitung untuk negara domisili turis asing agar wisatawan yang ingin berkunjung dapat lebih mudah mengakses pariwisata Kabupaten Belitung. Hal ini dapat dilakukan dengan negosiasi dengan sektor-sektor terkait penerbangan, baik di pemerintah maupun swasta, seperti Kementerian Perhubungan, Angkasa Pura dan maskapai penerbangan, baik swasta maupun BUMN.

Pemerintah daerah perlu membentuk visi dan misi khusus berkenaan dengan implementasi KEK yang dapat dijalankan antar instansi pemerintah daerah sehingga dalam implementasinya masing-masing aktor memiliki tujuan dan dapat melakukan koordinasi antar sektor dengan lebih baik. BUPP perlu melakukan perencanaan ulang berkaitan dengan target investasi yang ingin direalisasikan, memasukan faktor hambatan dalam pariwisata Kabupaten Belitung ke dalam perencanaannya sehingga target investasi yang dimuat akan lebih realistis untuk dicapai.

\section{DAFTAR PUSTAKA}

Agustino, L. (2012). Dasar-Dasar Kebijakan Publik. Bandung: CV Alfabeta.

Babbie, E. (2010). The Practice of Social Research (ed.). Wadsworth: Nelson Education Ltd. Belitongekspres. (2017, August 30). Sengketa Lahan KEK Bakal Diselesaikan. Retrieved from https://belitongekspres.co.id/sengketa-lahan-kek-bakal-diselesaikan

Belitung Maritime Ecotourism Development. (2019). Laporan KEK Tanjung Kelayang. Retrieved from https://kek.go.id/tanjung-kelayang

Bhuiyan, A. H., Siwar, C., \& Ismail, S. M. (2013). Tourism Development in Malaysia from the Perspective of Development Plans. Asian Social Science, 9(9), 11-18. https://doi.org/10.5539/ass.v9n9p11

Birkland, T. A. (2015). An introduction to the Policy Process: Theories, Concepts, and Models of Public Policy Making. Routledge.

BPS. (2018). Produk Domestik Regional Bruto Provinsi-Provinsi di Indonesia Menurut Lapangan Usaha. 
Cerna, L. (2013). The Nature of Policy Change and Implementation: a Review of Different Theoretical Approaches. ILE.

CNBC Indonesia. (2018, August 28). Begini Nasib Kawasan Ekonomi Khusus Saat Ini. Retrieved from https://www.cnbcindonesia.com/news/20180828135834-430557/begini-nasib-kawasan-ekonomi-khusus-saat-ini

CNN Indonesia. (2016, December 10). Tanjung Kelayang: KEK yang Cepat Pembangunannya. Retrieved from https://www.cnnindonesia.com/gayahidup/20161210183847-307-178720/tanjung-kelayang-kek-yang-cepatpembangunannya. Diakses pada tanggal 10 Maret 2019

Cochran, C. E., Mayer, L. C., Carr, T. R., Cayer, N. J., \& McKenzie, M. (2015). American Public Policy: An Introduction. Nelson Education.

Cresswell, J. W. (2010). Research Design Pendekatan Kualitatif, Kuantitatif, dan Mixed Edisi ketiga. Yogyakarta: Pustaka Pelajar.

Dewan Nasional Ekonomi Khusus. (2018). Laporan Tahunan Kawasan Ekonomi Khusus 2017. Retrieved from https://kek.go.id/laporan-akhir-tahun

Dewan Nasional Ekonomi Khusus Republik Indonesia. (2017, July 5). KEK Tanjung Kelayang, Kelas Dunia Namun Inklusif. Retrieved from https://kek.go.id/berita/2017/07/KEK-Tanjung-Kelayang-Kelas-Dunia-NamunInklusif

Fadhillah, Nuurul dan Vishnu Juwono (2020). Application of Five Stream Framework Concept in E-Procurement Implementation in Depok: A Review of Literature. Jurnal Administrasi Publik, 18(1), 121-141. https://doi.org/10.30996/dia.v18i1

Febriyanti, Anisa and Vishnu Juwono (2017). The Acceleration of Food Consumption Diversity Policy Implementation through Sustainable Food-Reserved Gardening: The Case of Jakarta. In T. Kurniawan et. all. (Eds.). Advances in Social Science, Education and Humanities Research, Volume 167. Paper presented at International Conference on Administrative Science, Policy and Governance (ICASPGS) 2017, (pp. 94 - 100). Paris, France: Atlantis Press.

Howlett, M. (2018). Moving Policy Implementation Theory Forward: A Multiple Streams/Critical Juncture Approach. Public Policy and Administration, 34(4), 405-430.

Howlett, M., \& Ramesh, M. (2003). Studying Public Policy: Policy Cycles and Policy Subsystems. Toronto, ON: Oxford University Press Canada.

Kementerian Koordinator Bidang Perekonomian. (2011). Masterplan Percepatan dan Perluasan Pembangunan Ekonomi Indonesia 2011-2025.

Khan, A. R., \& Khandaker, S. (2016). A critical insight into policy implementation and implementation performance. Public Policy and Administration, 15(4), 538-548. https://doi.org/10.13165/VPA-16-15-4-02

Kusumanegara, S. (2010). Model dan Aktor dalam Proses Kebijakan Publik. In Gava Media. Gava Media.

May, C. (2013). Towards a General Theory of Implementation. Implementation Science, 8(18). https://doi.org/10.1186/1748-5908-8-18

Moberg, L. (2015). The Political Economy of Special Economic Zones. Journal of Institutional Economics, 11(1), 167-190. https://doi.org/10.1017/S1744137414000241

Nilsen, P. (2015). Making sense of implementation theories, models and frameworks. Implementation Science, 10(53). https://doi.org/10.1186/s13012-015-0242-0

Nilsen, P., Ståhl, C., Roback, K., \& Cairney, P. (2013). Never the twain shall meet? - a comparison of implementation science and policy implementation research. Implementation Science, 8(63). https://doi.org/10.1186/1748-5908-8-63 
Pakdeenurit, P., Suthikarnnarunai, N., \& Rattanawong, W. (2014). Special Economic Zone: Facts, Roles, and Opportunities of Investment. Lecture Notes in Engineering and Computer Science.

Peraturan Gubernur Nomor 21 Tahun 2017 tentang Penetapan Dinas Penanaman Modal, Pelayanan Terpadu Satu Pintu dan Perindustrian Kabupaten Belitung Sebagai Administrator Kawasan Ekonomi Khusus Tanjung Kelayang.

Peraturan Pemerintah Nomor 2 Tahun 2011 tentang Penyelenggaraan Kawasan Ekonomi Khusus.

Sadono, S. (2010). Makroekonomi. Teori Pengantar. Depok: PT. RajaGrafindo Persada.

Sjafrizal. (2012). Pertumbuhan Ekonomi dan Ketimpangan Regional Wilayah Indonesia Bagian Barat. Jurnal Buletin Prisma.

Smith, K. B., \& Larimer, C. W. (2018). The Public Policy Theory Primer. In The Public Policy Theory Primer. Westview Press. https://doi.org/10.4324/9780429494352

Strehlenert, H., Richter-Sundberg, L., Nyström, M. E., \& Hasson, H. (2015). Evidenceinformed policy formulation and implementation: A comparative case study of two national policies for improving health and social care in Sweden. Implementation Science, 10(169). https://doi.org/10.1186/s13012-015-0359-1

Umar, H. (2008). Metode penelitian untuk skripsi dan tesis bisnis. Depok: PT RajaGrafindo Persada.

Undang-Undang Nomor 25 Tahun 2007 tentang Penanaman Modal, (2007).

Undang-Undang Nomor 39 Tahun 2009 tentang Kawasaan Ekonomi Khusus, (2009) (testimony of Undang-Undang Republik Indonesia).

Winarno, B. (2007). Kebijakan Publik: Teori dan Proses. Yogyakarta: Media Pressindo. 